кандидат педагогічних наук, доцент кафедри теорії і методики дошкільної

та початкової освіти

Кременецької обласної гуманітарнопедагогічної академії ім. Тараса Шевченка, м. Кременець, Україна ORCID: 0000-0002-1521-0428 e-mail: ionuschyk@gmail.com

\title{
РОЗВИТОК ОСОБИСТОСТІ МАЙБУТНЬОГО ВИХОВАТЕЛЯ ЗДО В КОНЦЕПЦІЇ ІННОВАЦИЙНОГО ФУНКЦІОНУВАННЯ СИСТЕМИ ВИЩОЇ ОСВІТИ
}

\begin{abstract}
Анотація. Стаття присвячена проблемі підготовки майбутніх вихователів ЗДО на сучасному етапі становлення вищої освіти. Зокрема, особлива увага надається проблемі розвитку особистості майбутнього фахівця, його культури самовираження в концепції інноваційного функціонування закладів вищої освіти. Висвітлюються результати аналізу наукових праць провідних науковців, присвячених інноваційній освіті майбутніх педагогів. На цій основі з'ясовується сутність та зміст дефініцій «інноваційність», «інноватика», «інноваційна діяльність», «інноваційна педагогічна діяльність», «інноваційна педагогічна діяльність майбутнього вихователя ЗДО», «особистісне зростання майбутнього вихователя ЗДО».

Особливе місце відводиться проблемі розвитку особистості студентів, їхньому морально-духовному становленню в сучасному закладі вищої освіти. Обгрунтовано, що впровадження педагогічної інноватики в освітній процес ЗДО є запорукою розвитку культури самовираження майбутнього фахівця. Феномен «культура самовираження майбутніх вихователів закладів дошкільної освіти» тлумачиться як особливості (відмінні від інших людей властивості особистості), способи (систематизована сукупність дій, використаних для досягнення мети), результати (проміжні та кінцеві продукти) самоорганізованої професійної діяльності. Зазначається також, що концепція дослідження забезпечується єдністю методологічного, теоретичного та методичного аспектів. Зроблено висновки дослідження та окреслено його перспективи.

Ключові слова: інноваційність, інноватика, інноваційна діяльність, інноваційна педагогічна діяльність, інноваційна педагогічна діяльність майбутнього вихователя ЗДО, особистісне зростання майбутнього вихователя ЗДО.
\end{abstract}

Постановка проблеми. Інноваційна освіта поступово стає домінуючою тенденцією в усьому світі, виступає альтернативою традиційній, знаннєвій парадигмі. У зв'язку 3 цим нова модель освіти покликана володіти такою якістю, як інноваційність.

Інтенсивні процеси трансформації системи освіти зумовили необхідність якісних змін у підготовці майбутніх педагогів, оскільки суспільство потребує фахівця, здатного продукувати нові прогресивні ідеї, нестандартно й ефективно вирішувати різноманітні проблеми, проявляти творчість, тобто бути готовим до інноваційної педагогічної діяльності. Особливо гостро ця проблема постає для ЗВО в процесі підготовки майбутніх вихователів закладів дошкільної освіти - педагогів-гуманістів, завдання яких - першими реагувати на виклики сучасності, по-новому сприймати 
систему «педагог - дитина», створювати сприятливі умови для прояву зростаючою особистістю різних форм активності з урахуванням іiї індивідуальності.

Аналіз останніх досліджень 3 проблеми. На сьогодні накопичився чималий науковий доробок, який висвітлює аспекти означеного феномену, а саме: теоретикометодологічні засади організації освітнього процесу у вищій школі (В. Андрущенко, I. Бех, О. Киричук, В. Кремень, I. Зязюн, В. Луговий, О. Сухомлинська та інші); підготовка майбутніх вихователів у ЗВО (Л. Артемова, Г. Бєлєнька, О. Богініч, А. Богуш, Н. Гавриш, Н. Гузій, І. Дичківська, Л. Зданевич, О. Кононко, І. Княжева, I. Луценко, Н. Лисенко, О. Листопад, О. Олійник, С. Нечай, Т. Поніманська, I. Рогальська-Яблонська, Т. Танько та інші).

Незважаючи на вагомий науковий доробок, проблема розвитку особистості, культури самовираження майбутніх фахівців дошкільної освіти в концепції інноваційного функціонування системи вищої освіти окремо не вивчалася. 3 огляду це виникає нагальна потреба у більш детальному дослідженні чинників особистісного зростання майбутнього вихователя ЗДО, розвитку його культури самовираження.

Мета статті - висвітлити аспекти особистісного становлення та розвитку культури самовираження майбутніх вихователів ЗДО в концепції інноваційного функціонування системи вищої освіти.

Виклад основного матеріалу дослідження. На думку науковців, стратегія досліджень педагогічної інноватики має враховувати сучасні демографічні процеси, ситуацію на ринку праці, ті зміни, що відбулися і відбуваються в чинниках (зовнішніх і внутрішніх), та впливають на розвиток різних галузей освіти (Бех, 2005, ВиноградоваБондаренко, 2005, Дичківська, 2013, Кремень, 2005, Машкіна, 2004, Бєлєнька, Богініч та Борисова, 2009, Сисоєва, 2005).

На думку А. Хуторського, педагогічна інноватика вивчає природу, закономірності виникнення та розвитку інновацій; їхній зв'язок із традиціями минулого і майбутнього стосовно суб'єктів освіти. Автор також зауважує, що на відміну від дидактики, де об'єктом наукового дослідження $є$ процес навчання, педагогічна інноватика досліджує трискладовий процес - тобто процес створення, засвоєння і застосування нововведень (2005). При цьому об'єктом педагогічної інноватики є процес виникнення, розвитку й освоєння інновацій в освіті, які сприяють прогресивним змінам та покращенню ії якості, а предметом - сукупність педагогічних умов, засобів і закономірностей, пов'язаних із розробкою, запровадженням та освоєнням педагогічних інновацій в освітній практиці. Відмінність педагогічної інноватики від інноватики в інших сферах полягає в особистісному чиннику (2005).

За висновками І. Дичківської, інноваційну педагогічну діяльність варто вважати «основою оновлення навчальних закладів, чинником розвитку освітніх систем». Ї̈̈ результат визначають структурні та змістові зміни в роботі закладу освіти (2013, c. 255). Отже, педагогічна інновація $є$ цілеспрямованою, осмисленою зміною педагогічної діяльності (та управління цією діяльністю) через напрацювання та впровадження в закладах освіти педагогічних та управлінських нововведень (нового змісту навчання, виховання, управління; нових способів професійної діяльності, організаційних форм, методів, технологій тощо) (2013).

Виходимо з розуміння, що як соціальний інститут підготовки студентської молоді до майбутньої професійної діяльності, відповідальний за формування в неї наукового світогляду, системи загальних та спеціальних знань, вмінь і навичок культурного самовираження у різних сферах життя, заклад вищої освіти має функціонувати в органічному взаємозв'язку з усією сукупністю соціокультурних факторів. Під впливом внутрішніх та зовнішніх чинників гуманізуються цілі і принципи педагогічної роботи, трансформується iï зміст, осучаснюються технології, задовольняються різноманітні освітні потреби суспільства та особистості, відбувається інтеграція в європейський та світовий освітній простір. 
Підготовка фахівців дошкільної освіти як першої іï ланки в сучасних умовах України має грунтуватися на синергетичному підході. Як зазначає О. Чалий, саме синергетичний підхід створив надійні засади для посилення інтеграційних тенденцій в освіті, пояснив єдність законів розвитку природи і суспільства, надав можливості інтегрування різних дисциплін, забезпечив більш глибоке розуміння існуючих міжпредметних зв'язків у вищій школі. Адже інноваційна діяльність характеризується системним характером (2002).

Досліджуючи проблему розвитку особистості в моделі інноваційного функціонування освітньої системи, О. Остапчук зауважує: «В українському суспільстві створюються об'єктивні передумови для перегляду теоретичних основ і технологій освіти, подолання репродуктивного стилю навчання і перехід до нової освітньої парадигми, спрямованої на розвиток пізнавальної активності молоді, іiі креативності, самостійності мислення. Саме вони є стратегічними напрямками модернізації системи освіти». Продовжуючи думку, вказаний вище автор стверджує, що інноваційні зміни продуктивно розгортаються лише в умовах синергії педагогічних систем. Обмін у процесі взаємодії суб'єктним досвідом усіх учасників $\epsilon$ запорукою збереження традицій і оновлення, збагачення набутого попереднього досвіду (2002).

Як зазначає А. Мазаракі, перехід на багаторівневу систему освіти передбачає, перш за все, докорінні зміни у змісті та структурі програм навчання студентської молоді, забезпечення спряженості дисциплін навчального плану. Адже йдеться про підготовку фахівців нового покоління, здатних професійно управляти педагогічними процесами в умовах, що постійно змінюються. Реструктуризація освітнього процесу на основі інноваційних технологій навчання зумовлює необхідність і можливість упорядкування самостійної роботи студентів і діагностики якості їхніх знань, умінь та якостей особистості (2002).

У контексті нашого дослідження викликає інтерес думка В. Кременя щодо соціальних інновацій та їхньої ролі в системі освіти. Як зазначає автор, соціальні інновації в освіті змінюють загальну архітектоніку самої системи освіти й, відповідно, сукупність діяльностей та взаємостосунків усіх, хто включений до процесів функціонування освітніх закладів. В. Кремень виділяє два фактори, які визначають дієвість і масштабність соціальних перетворень, до яких належить:

- по-перше, суспільну та інституційну готовність держави та суспільства до їх прийняття;

- по-друге, систему соціально-педагогічних інновацій, спрямованих на зміну внутрішніх умов організації процесів навчання та виховання.

Як підкреслює В. Кремень, узагальненими критеріями оцінки таких інновацій $є$ : ступінь відповідності форм освітніх інституцій потребам суспільства та ступінь відповідності форм організації освіти умовам повноцінного психосоціального розвитку його суб'єктів (2005).

Згідно з позицією І. Беха, проблема розвитку досконалої особистості передбачає впровадження в педагогічну практику інноваційних технологій. Суттєві науковопрактичні надбання вказаний автор пов'язує із системно-цільовою виховною орієнтацією, в якій тактика попередження виховних відхилень і свідомого спрямування людини на бік добра є домінуючою. Науковець зазначає: «Моральнодуховна істина як сутність вищого рівня утримується в людській культурі як у формі тих чи інших наукових теорій, так і в формі особистісно-персоніфікованій, в якій зафіксовані морально-духовні шукання конкретних персоналій». І. Бех підкреслює, що зона найближчого морально-духовного розвитку особистості є особливим проблемним полем, тому педагогові слід проявляти справжню методичну віртуозність. Іїі ключовою ознакою $є$ забезпечення в освітньому процесі несуперечливого переходу від спільного (педагога та студента) цілепокладання до відповідального цілепокладання. Фахівець акцентує увагу на тому, що поклик потенційного духовного у внутрішньому світі суб' єкта розгортається як самовираження, яке саме в собі містить мотив до дії (2005). 
Згідно $з$ науковою позицією В. Мудрака, в умовах інформаційного суспільства, в якому головним ресурсом і потенціалом $є$ людина у системі інформації, новітніх технологій, виникають інноваційні підходи до розвитку вищої освіти. Ці підходи грунтуються на розумінні того, що культурно-духовні надбання $\epsilon$, 3 одного боку, результатом індивідуальної й колективної науково-технологічної обробки інформації, духовно-ціннісного досвіду, з іншого - продуктом споживання й виробництва матеріального і духовного. Автор актуалізує необхідність інновацій в онтологічній, гносеологічній, пізнавальній, праксеологічній, аксіологічній реальності суспільних і соціальних відносин у вищій освіті (2005).

Згідно з науковою позицією С. Сисоєвої, у відкритому світі, де майбутнє не може бути чітко прогнозованим, а теперішнє має декілька потенційних ліній розвитку, людина перебуває в ситуації постійного вибору, пошуку оптимального рішення у швидкозмінних умовах життя. Тому в закладі вищої освіти мають створюватися умови для розвитку творчих якостей особистості студентів, їх підготовки до професійної праці. На думку автора, це завдання передусім педагогічних технологій, які в сучасному освітньому просторі можна розглядати як організаційний початок, який запускає у дію і направляє творчі сили носіїв наукових знань і педагогічного досвіду. Педагогічна технологія розглядається С. Сисоєвою як продумана у всіх деталях модель спільної педагогічної діяльності з проєктування, організації і проведення освітнього процесу з безумовним забезпеченням комфортних умов для всіх його учасників (2005).

У контексті проблеми розвитку інноваційної діяльності закладів вищої освіти привертає увагу дослідження В.Виноградової-Бондаренко, присвячене розвитку креативного мислення у студентської молоді. Автор підкреслює, що в процесі розвитку творчої особистості велика роль належить викладачеві, здатному спрямувати студентів на шлях пошуків, викликати в них інтерес до пошукової діяльності, уводити майбутніх фахівців в атмосферу творчості, у коло ідей, робота 3 якими розкриває широкі можливості для самостійного пошуку (2005).

Акцентуючи увагу на важливості формування в майбутніх фахівців дошкільної освіти свідомого ставлення до професійної діяльності, використання інноваційних технологій у роботі з дошкільниками, плекання творчої активності, О. Прокопенко наголошує: потрібен новий погляд на педагогічну реальність, переосмислення шляхів і перспектив подальшого розвитку особистості педагога-фахівця, упровадження інноваційних технологій у свою професійну діяльність. Як підкреслює вказаний автор, тільки творчий педагог здатний створювати середовище, сприятливе для розвитку творчої особистості дитини. Фахівець зазначає, що для педагога дошкільної освіти винятково важливим є усвідомлення того, що результат праці має індивідуальний творчий характер, а регуляція професійних взаємин обумовлюється становленням адекватної «Я-концепції» (2012).

У контексті зазначеної проблеми заслуговує на увагу дослідження Л. Машкіної, яка розробила модель підготовки майбутнього вихователя закладу дошкільної освіти до використання інноваційних технологій. Автор розглядає її як поданий у словесній формі структурно-функціональний аналог, в якому закладено механізм цієї підготовки. Вищезазначену компетентність Л. Машкіна тлумачить як систему мотивів, знань, умінь та навичок, особистісних якостей, що забезпечують ефективність використання сучасних педагогічних технологій в роботі з дошкільниками (2004).

Висновки і перспективи подальших розвідок. У дослідженні ми виходимо 3 позиції, що професіоналізація майбутнього вихователя закладу дошкільної освіти, його входження в інноваційний режим роботи неможливі без творчого самовизначення, в якому провідну роль відіграють інноваційні педагогічні технології. Під інноваційною освітою розуміємо орієнтовані на динамічні зміни у навколишньому світі та самому собі навчальні та виховні дії, спрямовані на розвиток креативного мислення, творчих здібностей, збалансованість індивідуальних та соціальних потреб особистості.

Перспективи подальших розвідок убачаємо в обгрунтуванні, апробації та 
впровадженні в освітній процес ЗВО педагогічних умов, форм та методів розвитку культури самовираження майбутніх вихователів ЗДО.

\section{СПИСОК ВИКОРИСТАНИХ ДЖЕРЕЛ}

Бех, І. (2005). Особистість у системі інноваційних виховних дій. В: Матеріали методологічного семінару АПН Украӥни 16 грудня 2004 р. Київ. с. 65-75.

Виноградова-Бондаренко, В. (2005). Розвиток креативного мислення у студентів. Матеріали методологічного семінару АПН України 16 грудня 2004 р. Київ. с. 471-473

Дичківська, I. (2013). Інноваційні педагогічні технології. Київ: Видавничий Дія «Слово». $448 \mathrm{c.}$

Кремень, В. (2005). Особистість в освітній системі. Теоретико-методологічні проблеми розвитку особистості в системі неперервної освіти. В: Матеріали методологічного семінару АПН Украӥни 16 грудня 2004 р. Київ. с. 3 -17.

Машкіна, Л. (2004). Підготовка студентів до впровадження педагогічних інновацій в дошкільних закладах. Хмельницький: ТОВ НВП, Евріка. 204 с.

Бєлєнька, Г., Богініч, О. та Борисова, 3. (2009). Підготовка вихователя до розвитку особистості дитини в дошкільному віці. Київ: Вид-во НПУ імені М. П. Драгоманова. 310 с.

Сисоєва, С. (2005). Педагогічні технології у сучасному освітньому просторі. В: Матеріали методологічного семінару АПН України 16 грудня 2004 р. Київ. с. 311-325.

Хуторской, А. (2005). Педагогическая инноватика: методология, теорія, практика. Москва: Изд-во ДО. 222 с.

Чалий, О. (2002). Синергетичний підхід - необхідна складова інтеграџійних процесів в освіті. Розвиток педагогічної і психологічної наук в Україні 1992-2002. Харків. «ОВС». Ч. 2. с. 125 - 133.

Остапчук, О. (2002). Розвиток особистості в моделі інноваційного функиіонування освітньої системи. Розвиток педагогічної і психологічної наук в Україні 1992-2002. Харків : «ОВС». Ч.2. с. 211-215.

Мазаракі, А. (2002). Модернізація вищої освіти на основі інноваційних технологій. Розвиток педагогічної і психологічної наук в Україні 1992-2002. Харків: «ОВС». Ч.2. с. 17-28.

Мудрак, В. (2005). Гуманістичні тенденції вищої освіти в інформаційному суспільстві. В: Матеріали методологічного семінару АПН Украӥни 16 грудня 2004 р. Київ, с.661-668.

Прокопенко, О. (2012). Професійна «Я-концепція» педагогів-дошкільників. Формування інноваційного простору дошкільної освіти. Київ. Ч.І 112 с.

\section{REFERENCES}

Bekh, I. (2005). Osobystist u systemi innovatsiinykh vykhovnykh dii [Personality in the System of Innovative Educational Actions]. V: Materialy metodolohichnoho seminaru APN Ukrainy 16 hrudnia 2004 r. Kyiv. s. 65-75. (in Ukrainian)

Vynohradova-Bondarenko, V. (2005). Rozvytok kreatyvnoho myslennia u studentiv [Development of Creative Thinking in Students]. V: Materialy metodolohichnoho seminaru APN Ukrainy 16 hrudnia 2004 r. Kyiv. s. 471-473. (in Ukrainian)

Dychkivska, I. (2013). Innovatsiini pedahohichni tekhnolohii [Innovative Pedagogical Technologies]. Kyiv: Vydavnychyi Diia "Slovo". 448 s. (in Ukrainian)

Kremen, V. (2005). Osobystist v osvitnii systemi. Teoretyko-metodolohichni problemy rozvytku osobystosti v systemi neperervnoi osvity [Personality in the Education System. Theoretical and Methodological Problems of Personality Development in the System of Continuous Education]. V: Materialy metodolohichnoho seminaru APN Ukrainy 16 hrudnia 2004 r. Kyiv. s. 3 -17. (in Ukrainian)

Mashkina, L. (2004). Pidhotovka studentiv do vprovadzhennia pedahohichnykh innovatsii $v$ doshkilnykh zakladakh. [Training of Students for the Implementation of 
Pedagogical Innovations in Preschool Institutions]. Khmelnytskyi: TOV NVP, Evrika. 204 s. (in Ukrainian)

Bielienka, H., Bohinich, O. ta Borysova, Z. (2009). Pidhotovka vykhovatelia do rozvytku osobystosti dytyny $v$ doshkilnomu vitsi [Preparation of Tutors for the Development of the Child's Personality at Preschool Age]. Kyiv: Vyd-vo NPU imeni M. P. Drahomanova. 310 s. (in Ukrainian)

Sysoieva, S. (2005). Pedahohichni tekhnolohii u suchasnomu osvitnomu prostori [Pedagogical Technologies in the Modern Educational Space]. V: Materialy metodolohichnoho seminaru APN Ukrainy 16 hrudnia 2004 r. Kyiv. s. 311-325. (in Ukrainian)

Khutorskoy, A. (2005). Pedagogicheskaya innovatyka: metodologiya, teoriya, praktika [Pedagogical Innovation: Methodology, Theory, Practice] . Moskva: Izd-vo DO. 222 s. (in Russian)

Chalyi, O. (2002). Synerhetychnyi pidkhid - neobkhidna skladova intehratsiinykh protsesiv v osviti [Synergistic Approach as a Necessary Component of Integration Processes in Education]. Rozvytok pedahohichnoi $i$ psykholohichnoi nauk v Ukraini 1992-2002 . Kharkiv. "OVS". Ch. 2. c. 125 - 133. (in Ukrainian)

Ostapchuk, O. (2002). Rozvytok osobystosti v modeli innovatsiinoho funktsionuvannia osvitnoi systemy [Personality Development in the Model of Innovative Functioning of the Educational System]. Rozvytok pedahohichnoi i psykholohichnoi nauk v Ukraini 1992-2002. Kharkiv : "OVS". Ch.2. s. 211-215. (in Ukrainian)

Mazaraki, A. (2002). Modernizatsiia vyshchoi osvity na osnovi innovatsiinykh tekhnolohii [Modernization of Higher Education on the Basis of Innovative Technologies] . Rozvytok pedahohichnoi i psykholohichnoi nauk v Ukraini 1992-2002. Kharkiv: "OVS". Ch.2. s. 17-28.

Mudrak, V. (2005). Humanistychni tendentsii vyshchoi osvity v informatsiinomu suspilstvi [Humanistic Tendencies in Higher Education in the Information Society] . V: Materialy metodolohichnoho seminaru APN Ukrainy 16 hrudnia 2004 r. Kyiv, s. 661-668. (in Ukrainian)

Prokopenko, O. (2012). Profesiina "Ya-kontseptsiia" pedahohiv-doshkilnykiv [Professional "I-concept" of Teacher-researchers]. Formuvannia innovatsiinoho prostoru doshkilnoi osvity. Kyiv. Ch.I. 112 s. (in Ukrainian)

\title{
DEVELOPMENT OF THE FUTURE PRE-SCHOOL TEACHERS' PERSONALITY IN THE CONCEPT OF INNOVATIVE FUNCTIONING OF THE HIGHER EDUCATION SYSTEM
}

\author{
Iryna Onyshchuk \\ Candidate of Pedagogical Sciences, Associate Professor, \\ Associate Professor at the Department of Theory and \\ Methodology of Preschool and Elementary Education, \\ Kremenets Taras Shevchenko Regional \\ Humanitarian and Pedagogical Academy, \\ Kremenets, Ukraine \\ ORCID: 0000-0002-1521-0428 \\ e-mail: ionuschyk@gmail.com
}

\begin{abstract}
The article is devoted to the problem of training of future teachers for preschool educational institutions at the present stage of the formation of higher education. The main attention is paid to the aspects of the future specialists' development, including their self-expression culture in the conception of innovative functioning of higher educational institutions. The results of analysis of the leading researchers' works dedicated to the innovative education of the future teachers were observed in the article. On this basis the essentiality and content of such definitions as "innovation", "innovative activity",
\end{abstract}


"innovative pedagogical activity", "innovative pedagogical activity of future pre-school teachers", "self-growing of future pre-school teachers" have been clarified.

The special place is given to the personal students' development, their moral and spiritual formation in the modern higher educational institutions. It was proved that the introduction of innovative methods in educational process is a guarantee of the self-culture development of future specialists. The phenomenon of "the self-expression culture of the future pre-school teachers" was explained as peculiarities, means and results of selforganized professional activity. The concept of researching is provided by the unity of the methodological, theoretical and methodical aspects. The conclusions of the research were realized and their prospects were described.

Keywords: innovation, innovative activity, innovative pedagogical activity, innovative pedagogical activity of future pre-school teachers, self-growing of future pre-school teachers.

Стаття надійшла до редакиії 16.09.2019 р. 